[Agr. Biol. Chem., Vol. 36, No. 8, p. 1327 1333, 1972]

\title{
Purification, Crystallization and Some Enzymatic Properties of Acid Protease of Cladosporium sp. No. 45-2
}

\author{
By Sawao Murao, Susumu Funakoshi* and Kohei Oda \\ Department of Agricultural Chemistry, College of Agriculture, \\ University of Osaka Prefecture
}

Received November 29, 1971

\begin{abstract}
An acid protease of Cladosporium sp. No. 45-2 was purified and crystallized by precipitation with ammonium sulfate, fractional precipitation with acetone, and pH adjustment. About $600 \mathrm{mg}$ of third crystallized preparation was obtained from one liter of culture broth. The purified enzyme was chromatographically homogeneous and confirmed to be monodispersive by physicochemical criteria such as ultracentrifugal and electrophoretical analysis. The enzyme was most active at $\mathrm{pH}$ values between 2.5 and 2.7 toward both casein and hemoglobin and was stable at $\mathrm{pH}$ values from 2.5 to 7.0 on twenty hour incubation at $30^{\circ} \mathrm{C}$.

Millimolar concentration of sodium lauryl sulfate markedly inbibited the enzyme, wheares diisopropyl phosphorofuoridate, sulfhydryl reagents, ethylenediaminetetra acetic acid, and divalent metal ion relatively little affected the activity. The enzyme was most resistant toward S-PI among the acid proteases tested.
\end{abstract}

On the way of screening of yeast which produce extracellular acid protease, a potent yeast like strain was obtained. As the results of taxonomical studies, the isolated strain was identified to be a strain belonging to Cladosporium. ${ }^{1 \prime}$

Many investigators ${ }^{2-81}$ have been studied on the acid protease produced from fungi, however, little is known on the acid protease of Cladosporium. So, we tried the purification and crystallization of the acid protease and studied the enzymatic and physicochemical properties on the crystalline preparation thus obtained.

The present paper describes the conditions of cultivation, purification procedures and some enzymatic properties of the acid protease of Cladosporium sp. No. 45-2.

$\uparrow$ Studies on Acid Protease of Cladosporium sp. No. 45-2. Part I. The report was presented at the Annual Meeting of the Agricultural Chemical Society of Japan at Tokyo, April, 1971.

* Present adress: Otsuka Pharmaceutical Co., Ltd., Tokushima.

\section{MATERIALS AND METHODS}

1. Assay of protease activity. The protease activity was measured by a modified Anson's method.9) To $3 \mathrm{ml} 4 / 30 \mathrm{o}$ milk casein solution containing $0.05 \mathrm{M}$ lactate buffer, $\mathrm{pH} 2.5$ was added $1 \mathrm{ml}$ of enzyme solution at $37 . \mathrm{C}$. After incubation for ten minutes, the reaction was stopped by an addition of $4 \mathrm{ml}$ of $0.44 \mathrm{M}$ trichloroacetic acid, followed by filtration. One $\mathrm{ml}$ of the filtrate was mixed with $5 \mathrm{ml}$ of $0.44 \mathrm{M} \mathrm{Na}_{2} \mathrm{CO}_{3}$ and then $1 \mathrm{ml}$ of Folin-Ciocalteu reagent was added to it. The optical density of the color developed was measured at $660 \mathrm{~m} / \mu$.

A unit of enzyme activity was defined as the enzyme quantity which liberate $1 / \mathrm{g}$ of tyrosine per $\mathrm{ml}$ of the reaction mixture per minute under the condition. The specific activity (unit/mg protein) was also measured according the assay method by Fukumoto et al. ${ }^{7}$

2. Determination of Protein. Protein content was assayed spectrophotometorically assuming that $E_{1 \% m}^{1 \%}$ at $280 \mathrm{~m} \mu$ of protein was 10.7, which was estimated from the dry weight of the purified enzyme preparation.

3. Organism. Cladosporium sp. No. 45-2 was isolated from the soil. The taxonomical study on Cladosporium sp. No. 45-2 will be reported in detail elsewhere. 
4. Ultracentrifugation. Sedimentation analysis was carried out at $25^{\circ} \mathrm{C}$ with a Beckmann Spinco model $\mathrm{E}$ analytical ultracentrifuge.

5. Moving-boundary electrophoresis. The procedure was carried out with a Hitachi-Tiselius electrophoresis apparatus model $\mathrm{HTB}-2$ at $5^{\circ} \mathrm{C}$.

6. Other proteolytic enzyme used. Rhizopus chinensis acid protease, ${ }^{7}$ Mucor pusillus rennin protease ${ }^{8 !}$ and Trametes sanguinea acid protease ${ }^{10}$ were kindly donated from Dr. Tsuru of Osaka City University, Dr. S. Iwasaki of Meitosangyo Co., Ltd., and Dr. K. Tomoda of Takeda Chemical Industries, respectively. Recrystallized pepsin was obtained from Washington Biochemical Co., Ltd. Partially purified preparation of Aspergillus saitoi acid protease ${ }^{5}$ was purchased from Yashima Drug Co., Ltd, and used after further purification. Rhodotolula glutinis acid protease ${ }^{11}$ was purified as reported previously.

\section{RESULTS AND DISCUSSION}

\section{Cultural condition for acid protease formation}

The effect of various nitrogen, carbon source on the formation of acid protease was investigated. The maximal formation of acid protease was observed when the medium in Table I was used. Investigating the effect of initial $\mathrm{pH}$ on protease formation using some 230 strains of yeast and yeast-like fungi, the authors $^{12}$ found that initial $\mathrm{pH}$ is very important factor for extracellular protease formation. That is, there were many strains producing extracellar protease when initial $\mathrm{pH}$ was adjusted at 3.0, whereas there were a few strains when initial $\mathrm{pH}$ at 6.5.

We also tested the effect of initial $\mathrm{pH}$ on the acid protease formation of Cladosporium sp.

Table I. Composition of Culture Medium

$\begin{array}{ll}\text { Sucrose } & 7 \% \\ \text { Polypeptone } & 2 \% \\ \mathrm{KH}_{2} \mathrm{PO}_{4} & 0.60_{0} \\ \mathrm{MgSO}_{4} \cdot 7 \mathrm{H}_{2} \mathrm{O} & 0.050_{0} \\ \mathrm{FeSO}_{4} \cdot 7 \mathrm{H}_{2} \mathrm{O} & 4 \mathrm{ppm} \\ \mathrm{MnSO}_{4} \cdot 4-6 \mathrm{H}_{2} \mathrm{O} & 4 \mathrm{ppm} \\ & \mathrm{pH} 3.0\end{array}$

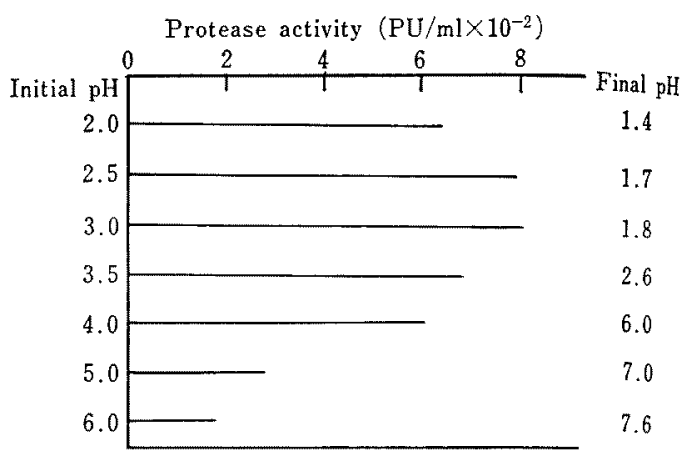

FIG. 1. Effect of Initial $\mathrm{pH}$ on the Production of Acid Protease.

The Cladosporium sp. No. 45-2 was aerobically grown at $25^{\circ} \mathrm{C}$ for 5 days in the medium shown in Table $\mathrm{I}$.

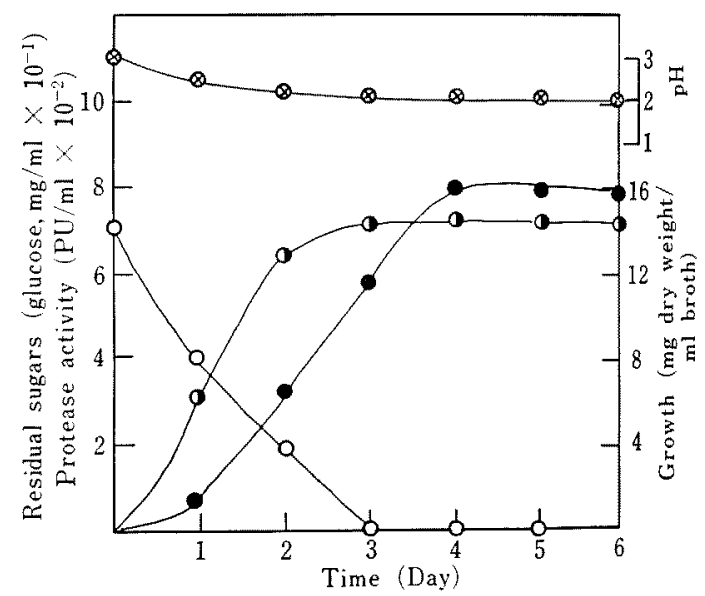

FIG. 2. Time Course of Acid Protease Production in Sucrose-Polypeptone Medium.

The Cladosporium sp. No. 45-2 was aerobically grown at $25^{\circ} \mathrm{C}$ in the medium indicated at Table I.

- Protease activity $(\mathrm{PU} / \mathrm{ml}), 0-0$ Growth (mg dry weight $/ \mathrm{ml}$ broth), $\mathrm{O}-\mathrm{O}$ Residual sugars (Glucose, $\mathrm{mg} / \mathrm{ml} \times 10^{-1}$ ), $\odot-\mathrm{pH}$

No. 45-2. As shown in Fig. 1, this strain showed a similar inclination described previously.

For Cladosporium sp. No. 45-2, the initial $\mathrm{pH}$, 3.0 , was optimum. Figure 2 illustrates the time course of acid protease formation in the medium. The $\mathrm{pH}$ of broth was gradually 
Table II. Summary of Purification Procedure of Cladosporium sp. No. 45-2 Acid Protease

\begin{tabular}{|c|c|c|c|c|c|}
\hline Procedure & $\mathrm{pH}$ & $\begin{array}{l}\text { Volume } \\
(\mathrm{ml})\end{array}$ & $\begin{array}{l}\text { Total activity } \\
\text { (units } \times 10^{-4} \text { ) }\end{array}$ & $\begin{array}{c}\text { Specific activity } \\
\text { (unit/O.D. } 280 \mathrm{~m} \mu \text { ) }\end{array}$ & $\begin{array}{l}\text { Yield } \\
(\%)\end{array}$ \\
\hline Culture filtrate & 2.0 & 10,000 & 800 & 110 & 100 \\
\hline \multicolumn{6}{|c|}{$\begin{array}{l}\left(\mathrm{NH}_{4}\right)_{2} \mathrm{SO}_{4} \text { precipitation and } \\
\text { dialysis }\end{array}$} \\
\hline \multirow{2}{*}{\multicolumn{6}{|c|}{ active carbon treatment }} \\
\hline & & & & & \\
\hline Filtrate & 3.0 & 800 & 720 & 550 & 90 \\
\hline \multicolumn{6}{|c|}{$\begin{array}{l}\text { acetone precipitation and } \\
\mathrm{pH} \text { adjustment }(\mathrm{pH} 4.5)\end{array}$} \\
\hline First crystals & - & - & 640 & 680 & 80 \\
\hline \multicolumn{6}{|c|}{$\begin{array}{l}\text { recrystallization, twice and } \\
\text { gel filtration }\end{array}$} \\
\hline Third crystals & - & - & 520 & 760 & 65 \\
\hline dialysis & & & & & \\
\hline Lyophilized preparation & - & - & 480 & 740 & 60 \\
\hline
\end{tabular}

lowered along with the consumption of sugar and retained at the range of 1.8 2.0. Protease production occured in about 1 day after inoculation and reached the maximum yield at $4 \sim 5$ days.

\section{Purification and crystallization of enzyme}

About 10 liters of culture broth was used. The protease was precipitated by the addition of solid ammonium sulfate to a final concentration of 0.8 saturation and allowed to stand overnight. The precipitate produced was collected by centrifugation $\left(4 \times 10^{4} \mathrm{~g}, 10 \mathrm{~min}\right)$,

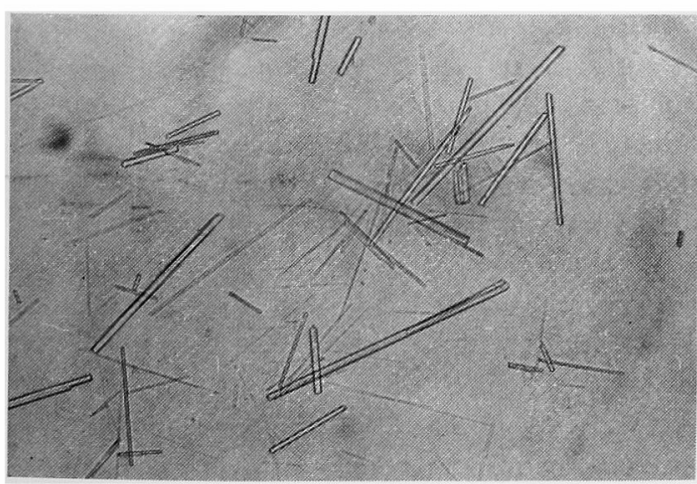

FIG. 3. Microscopic Photograph of Cladosporium sp. No. 45-2 Acid Protease.

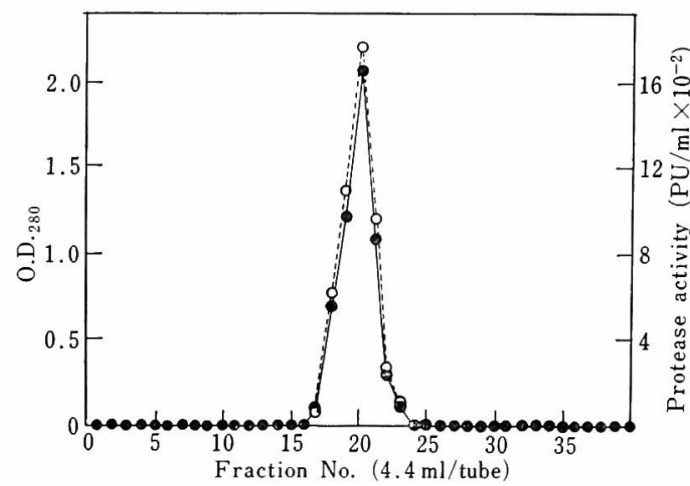

FIG. 4. Column Chromatogram of Purified Enzyme on Sephadex G-100.

About $40 \mathrm{mg}$ of purified enzyme was applied on a column $(2.5 \times 35 \mathrm{~cm})$ which was equilibrated with $10^{-2} \mathrm{M}$ citrate buffer, $\mathrm{pH} 3.0$.

-—: O.D. $280 \mathrm{~m} \mu, \bigcirc-\mathrm{O}$ : Protease activity

dissolved in $10^{-2} \mathrm{M}$ citrate buffer, $\mathrm{pH} 3.0$, and dialyzed against the same buffer using a visking tube overnight. The dialyzed solution, $600 \mathrm{ml}$, was treated with active carbon $(0.2 \%$ $\mathrm{w} / \mathrm{v})$, twice, and the colorless filtrate, $800 \mathrm{ml}$, was mixed with three volumes of cold acetone. The resulting precipitate was collected by centrifugation and dissolved in the same buffer 


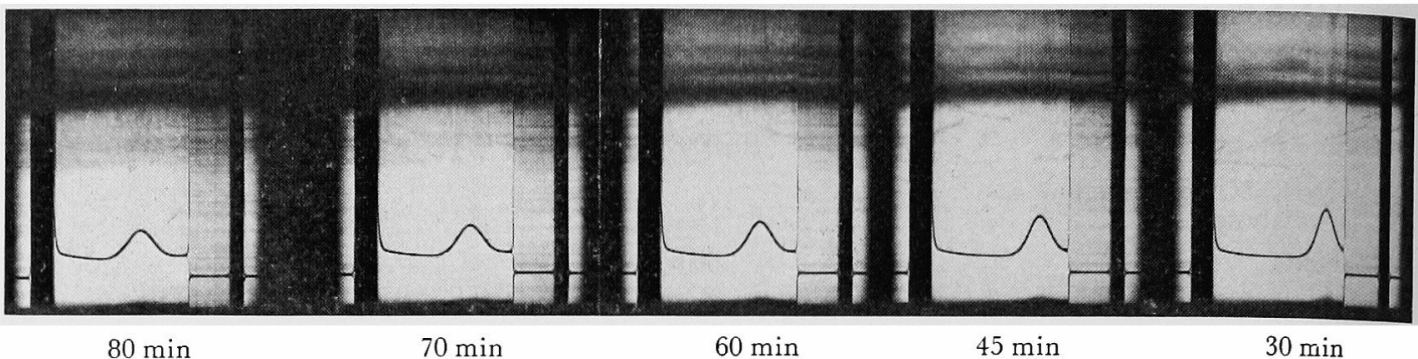

FIG. 5. Sedimentation Patterns of Acid Protease.

About one per cent enzyme solution in $10^{-2} \mathrm{M}$ citrate buffer, $\mathrm{pH} 4.0$ containing $\mathrm{NaCl}$ $(\mu=0.1)$. Temperature was $25^{\circ} \mathrm{C}$. The photographs were taken at indicated times reaching after full speed $(56,000 \mathrm{rpm})$.

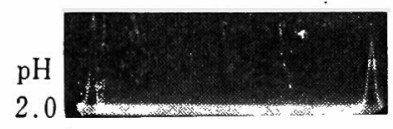

3.0

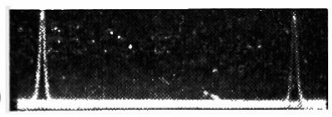

4.0
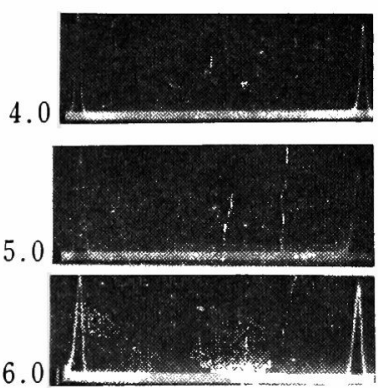

$0 \mathrm{~min}$
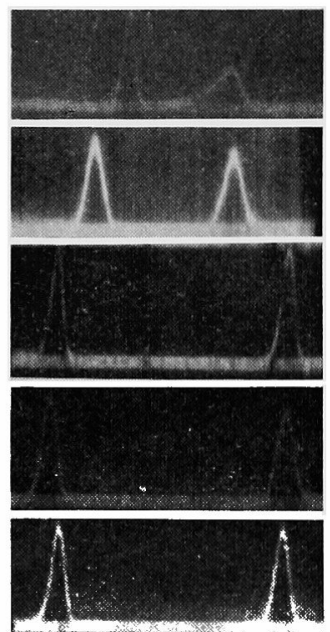

$180 \mathrm{~min}$

FIG. 6. Moving-boundary Electrophoretic Patterns of Acid Protease.

The electrophoretic migration was carried out in acetate buffer over a $\mathrm{pH}$ range of 2.0 to 4.0 , citrate

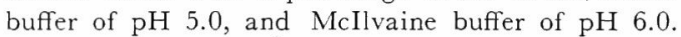
The ionic strength of the buffer solution was 0.1 . The current was $10 \mathrm{~mA}$ at $5{ }^{\circ} \mathrm{C}$. The ascending and descending boundaries are shown $180 \mathrm{~min}$ after the start of electrophoresis.

described above as small quantity as possible. After removing the insoluble impurities by centrifugation, if any, the $\mathrm{pH}$ of the clear solution was adjusted to 4.5 with $10^{-1} \mathrm{M}$ sodium citrate solution. The crystals appeared after about fifteen hours. The crude crystals were washed with $10^{-3} \mathrm{M}$ citrate buffer, $\mathrm{pH} 4.5$,

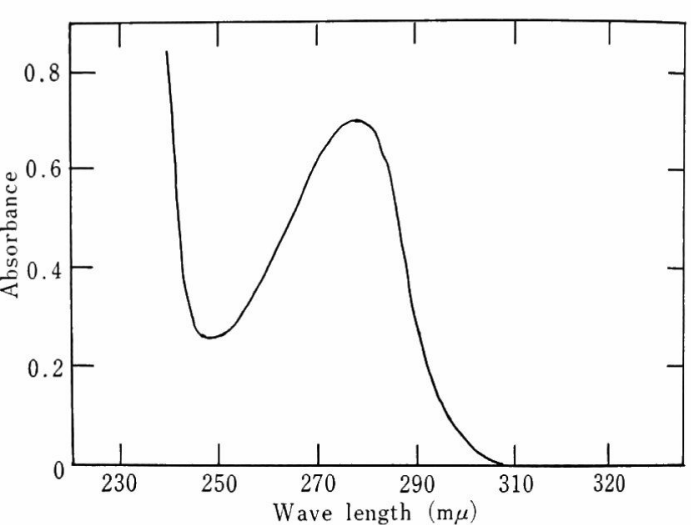

FIG. 7. Ultraviolet Absorption Spectrum of Acid Protease.

dissolved in $10^{-2} \mathrm{M}$ citrate buffer, $\mathrm{pH} 3.0$, as small quantity as possible and recrystallized twice. The crystal were dissolved in a small amount of $10^{-3} \mathrm{M}$ citrate buffer solution, $\mathrm{pH}$ 3.0 and chromatographed on a column of Sephadex G-100 $(2.5 \times 40 \mathrm{~cm})$ equilibrated with the same buffer. The active fractions were collected and crystallized as described above. The purified preparation was dissolved in $10^{-3} \mathrm{M}$ acetate buffer, $\mathrm{pH} 3.0$ and dialyzed against $10^{-4} \mathrm{M}$ hydrochloric acid solution at $4^{\circ} \mathrm{C}$ and then lyophilized with little loss of activity. About $6 \mathrm{~g}$ of the purified enzyme were obtained, amounting to about $65 \%$ recovery of the total proteolytic activity. The purification procedure is summarized in Table II, and the 
photograph of crystalline enzyme is shown in Fig. 3.

Homogeneity of the lyophilized preparation was checked by chromatography on a Sephadex G-100 column equilibrated with $10^{-2} \mathrm{M}$ citrate buffer, $\mathrm{pH} 3.0$ and a single symmetrical peak with a constant specific activity of 760 (PU/ O.D. at $280 \mathrm{~m} \mu$ ) at $\mathrm{pH} 2.5$ was found as shown in Fig. 4.

Ultracentrifugal and moving boundary electrophoretical analysis showed that the preparation was monodispersive (Figs. 5 and 6 ).

The ultraviolet absorption spectrum of the enzyme is shown in Fig. 7.

\section{Enzymatic properties}

a) Effect of $p H$ on activity and stability of the enzyme. Figure 8 illustrates the effect of $\mathrm{pH}$ on the protease activity. The $\mathrm{pH}$ of casein and hemoglobin substrate was adjusted by the following buffers: $10^{-1} \mathrm{M}$ citrate buffer $(\mathrm{pH}$ 1.0 3.0), Mcllvaine buffer $(\mathrm{pH} \quad 2.0 \sim 6.0)$, and $10^{-1} \mathrm{M}$ glycine-hydrochloric acid $(\mathrm{pH} 2.5 \sim$ $3.0)$. The protease was most active at $\mathrm{pH}$ values between 2.5 and 2.7 toward both substrates.

To check the pH stability relationship, the

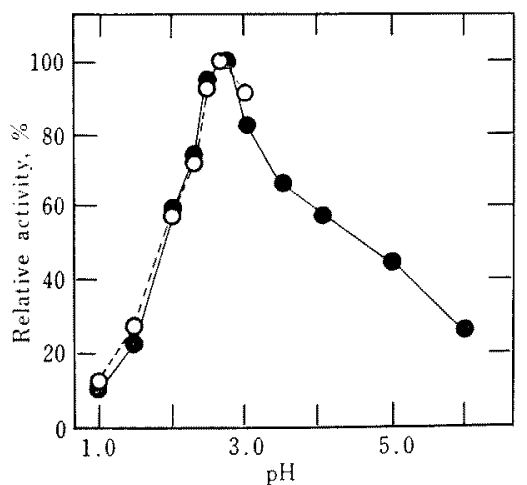

FIG. 8. Effect of $\mathrm{pH}$ on Protease Activity.

Casein and hemoglobin were used as substrate. The reaction was carried at various $\mathrm{pH}$ values and $37^{\circ} \mathrm{C}$ for $10 \mathrm{~min}$. See the text for the experimental details.

$$
\text { o-o: Casein, }
$$$$
\text { Hemoglobin }
$$

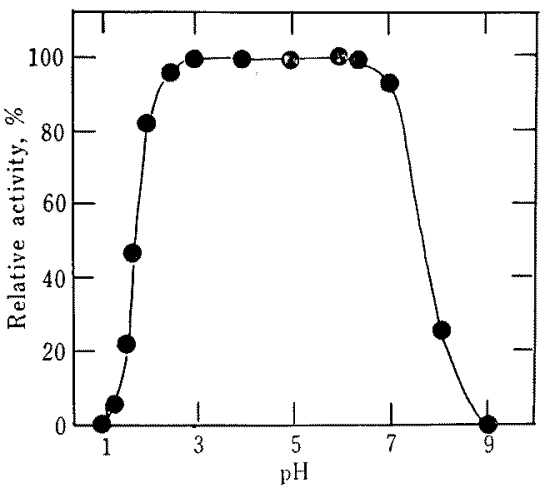

FIG. 9. Effect of $\mathrm{pH}$ on the Stability of Acid Protease.

Enzyme solutions were incubated at each $\mathrm{pH}$ for $20 \mathrm{hr}$ at $30^{\circ} \mathrm{C}$ and the remaining activities were assayed at $\mathrm{pH} 2.5$.

enzyme was diluted with $10^{-1} \mathrm{M}$ buffer of various $\mathrm{pH}$ values and incubated at $30^{\circ} \mathrm{C}$ for $20 \mathrm{hr}$. No loss of enzyme activity was observed at $\mathrm{pH}$ values between 2.5 and 6.5. (Fig. 9)

b) Temperature optimum of the enzyme reaction and thermal stability of the enzyme. The enzyme reaction was carried out at various temperature at $\mathrm{pH} 2.5$ for ten minutes. The temperature optimum was at $55^{\circ} \mathrm{C}$ (Fig. 10). As shown in Fig. 11, the enzyme lost its activity after ten minutes incubation at $70^{\circ} \mathrm{C}$ at $\mathrm{pH} 2.5$.

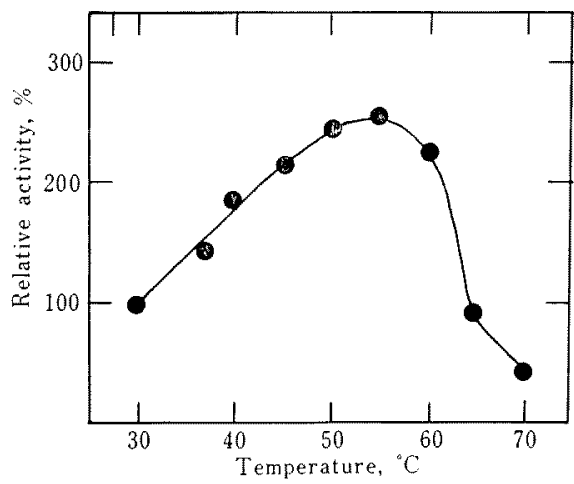

FIG. 10. Effect of Temperature on Enzyme Reaction.

The reation was carried out for $10 \mathrm{~min}$ at $\mathrm{pH} 2.5$ with casein at various temperatures. 


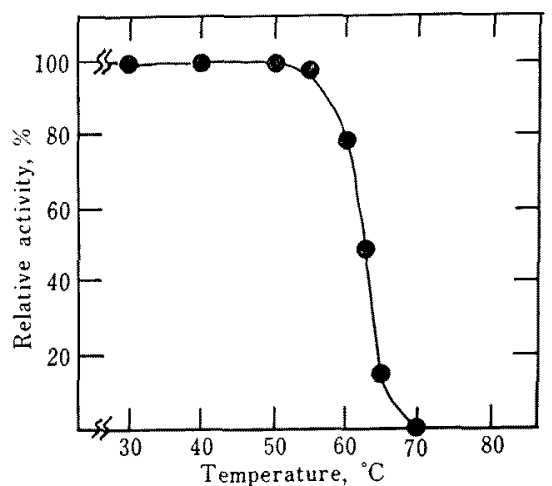

FIG. 11. Thermal Stability of Acid Protease.

Enzyme solutions were incubated at each temperature for $10 \mathrm{~min}$ at $\mathrm{pH} 2.5$ and the remaining activities were assayed at $37^{\circ} \mathrm{C}$.

\section{TABLE III. EFFECT OF VARIOUS ReAGENTS ON ENZYME ACTIVITY}

The enzyme, $10 \mu \mathrm{g} / \mathrm{ml}$, was incubated at $37^{\circ} \mathrm{C}$ for $15 \mathrm{~min}$ with various chemicals at $\mathrm{pH} 4.0$ or 6.0 , and then the remaining activity was assayed at $\mathrm{pH} 2.5$.

\begin{tabular}{|c|c|c|}
\hline Chemicals & $\begin{array}{l}\text { Concentration } \\
\text { (mM) }\end{array}$ & $\underset{(0)}{\text { Remaining activity }}$ \\
\hline None & - & 100 \\
\hline $\mathrm{HgCl}_{2}$ & 1.0 & 93 \\
\hline $\mathrm{PbCl}_{2}$ & 10.0 & 100 \\
\hline $\mathrm{MnCl}_{2}$ & 10.0 & 100 \\
\hline $\mathrm{CdCl}_{2}$ & 10.0 & 100 \\
\hline $\mathrm{FeCl}_{2}$ & 10.0 & 100 \\
\hline $\mathrm{NiCl}_{2}$ & 10.0 & 90 \\
\hline $\mathrm{ZnCl}_{2}$ & 10.0 & 90 \\
\hline $\mathrm{CuCl}_{2}$ & 10.0 & 100 \\
\hline $\mathrm{CoCl}_{2}$ & 10.0 & 100 \\
\hline $\mathrm{FeSO}_{4}$ & 10.0 & 100 \\
\hline IAA & 10.0 & 90 \\
\hline $\mathrm{NaNO}_{2}$ & 10.0 & 100 \\
\hline $\mathrm{I}_{2}$ & 10.0 & 100 \\
\hline $\mathrm{KMnO}_{4}$ & 1.0 & 80 \\
\hline SLS & 1.0 & 0 \\
\hline PCMB & 1.0 & 85 \\
\hline EDTA & 10.0 & 100 \\
\hline DFP & 1.0 & 100 \\
\hline
\end{tabular}

c) Effect of various protease inhibitors, surface active reagents and sulfhydryl reagents. The enzyme was markedly inactivated by SLS but slightly by divalent metal ions such as $\mathrm{Hg}^{2+}$, $\mathrm{Ni}^{2+}, \mathrm{Zn}^{2+}$ as shown in Table III.

Sulfhydryl reagent was also slightly inhibitory for the enzyme.

d) Effect of Streptomyces-pepsin inhibitor ( $S$ $P I)^{131} \quad$ Effect of S-PI on the protease activity was tested, comparing with various acid proteases at optimal $\mathrm{pH}$. The activity of pepsin

TABLE IV. EFFECT of Streptomyces-PePsin InHibitoR (S-PI) ON VARIOUS ACID Protease

The enzyme, I $\mathrm{mg} / \mathrm{ml}$, was incubated at $37^{\circ} \mathrm{C}$ for $10 \mathrm{~min}$ with equal volume of S-PI at optimum $\mathrm{pH}$ and the remaining activity was assayed.

\begin{tabular}{|c|c|c|}
\hline Protease & $\begin{array}{l}\text { Concen- } \\
\text { tration } \\
(\mu \mathrm{g})\end{array}$ & $\begin{array}{l}\text { Remaining } \\
\text { activity } \\
(\%)\end{array}$ \\
\hline \multirow[t]{3}{*}{ Cladosporium sp. No. $45-2$ acid } & 20 & 80 \\
\hline & 40 & 65 \\
\hline & 60 & 55 \\
\hline \multirow[t]{3}{*}{ Rhodotorula glutinis $\mathrm{K} \cdot 24$ acid } & 20 & 40 \\
\hline & 40 & 25 \\
\hline & 60 & 20 \\
\hline Pepsin & 20 & 0 \\
\hline \multirow[t]{3}{*}{ Trametes sanguinea acid } & 20 & 65 \\
\hline & 40 & 50 \\
\hline & 60 & 42 \\
\hline \multirow[t]{3}{*}{ Rhizopus chinensis acid } & 20 & 42 \\
\hline & 40 & 25 \\
\hline & 60 & 22 \\
\hline Aspergillus saitoi acidal & 20 & 55 \\
\hline \multicolumn{3}{|c|}{ a) Partially purified preparation. } \\
\hline \multicolumn{3}{|c|}{$\begin{array}{c}\text { Table V. Proteolytic ACtivity of Several } \\
\text { Protease }\end{array}$} \\
\hline Protease & \multicolumn{2}{|c|}{$\begin{array}{l}\text { Specific activity } \\
\text { (units/mg protein) } \\
\text { at optimum } \mathrm{pH}\end{array}$} \\
\hline Cladosporium sp. No. 45-2 acid & \multicolumn{2}{|r|}{3,400} \\
\hline Rhodotorula glutinis K-24 acid & \multicolumn{2}{|r|}{5,200} \\
\hline Pepsin & \multicolumn{2}{|c|}{3,000} \\
\hline Rhizopus chinensis acid & \multicolumn{2}{|r|}{2,200} \\
\hline Aspergillus saitoi acidal & \multicolumn{2}{|r|}{2,000} \\
\hline Trametes sanguinea acid & \multicolumn{2}{|r|}{2,200} \\
\hline
\end{tabular}

a) This data was quoted from the paper of Fukumoto et al. ${ }^{\text {l }}$ 
$\left(2.9 \times 10^{-8} \mathrm{M}\right)$ was completely inactivated by $20 \mu \mathrm{g}$ S-PI $\left(3.1 \times 10^{-8} \mathrm{M}\right)$, whereas those of other protease were remained active. Among the acid protease tested, Cladosporium sp. No. 45-2 acid protease was most resistant toward S-PI. (Table IV)

e) Comparative activity. The specific activity of the acid protease obtained here was estimated to be 3,400 on casein substrates according the assay method by J. Fukumoto et al. As shown in Table $V$, the value indicates that the enzyme shows somewhat high activity than that of pepsin. The enzyme was more active than the acid proteases produced from Rhizopus chinensis, Aspergillus saitoi, Trametes sanguinea but less active than that produced from Rhodotorula glutinis K-24.

\section{REFERENCES}

1) S. Murao, M. Kamada, T. Nakase, S. Ogura and K. Oda, Nippon Nogeikagaku Kaishi, 46, 167
(1972).

2) T. Hofmann and R. Shaw, Biochim, Biophys. Acta, 92, 543 (1964).

3) W. E. Marshall, R. Manion and J. Porath, ibid., 151, 414 (1968).

4) K. Nakanishi, J. Biochem. (Tokyo), 46, 1263 (1959).

5) F. Yoshida and M. Nagasawa, Bull. Agr. Chem. Soc. Japan, 20, 257 (1956).

6) J. Sawada, Agr. Biol. Chem., 27, 677 (1964).

7) J. Fukumoto, D. Tsuru and T. Yamamoto, ibid., 31, 710 (1967).

8) J. Yu, S. Iwasaki, G. Tamura and K. Arima, ibid., 32, 1051 (1968).

9) S. Akabori, "Method of Enzyme Research," Asakura Book Co., Ltd., 2, 1956, p. 240.

10) K. Tomoda and H. Shimazono, Agr. Biol. Chem, 28, 770 (1964).

11) M. Kamada, K. Oda and S. Murao, ibid., 36, 1095 (1972).

12) M. Kamada, S. Ogura, K. Oda and S. Murao, Nippon Nogeikagaku Kaishi, 46, 171 (1972).

13) S. Murao and S. Satoi, Agr. Biol. Chem., 35, 1477 (1971). 